\title{
Social Interaction Between Etnics in Market Mastery in Sungai Penuh City Market in Kerinci Regency in a Sociological Prepective
}

\author{
$1^{\text {st }}$ Eka Putri Hardiyanti \\ Dep. of Sociology Education, \\ Faculty of Pascasarjana \\ Universitas Negeri Padang, Padang, Indonesia \\ eka.putri1309@gmail.com
}

\author{
$2^{\text {nd }}$ Susi Evanita* \\ Dep. of Sociology Education, \\ Faculty of Pascasarjana \\ Universitas Negeri Padang, Padang, Indonesia \\ susievanita@gmail.com
}

\begin{abstract}
The purpose of this study is to describe the social interaction between traders in controlling the market in Sungai Penuh in Kerinci Regency. The purpose of this study looks at 1) Research on the interaction between migrants and Kerinci natives, 2) factors that encourage socio-economic relations between ethnic migrants and Kerinci natives in the Sungai Penuh City market 3) Form of Mastery of Ethnic immigrants to the Kerinci ethnic group. This type of research is qualitative research using data collection techniques through observation, in-depth interviews and utilizing document studies. The selection of informants based on certain considerations (purposive sampling). Data analysis uses an interactive model that includes 3 steps: 1) data reduction, 2) data presentation, 3 ) data verification (withdrawal), 3) conclusion.The results of the study indicate that the process of social interaction between
\end{abstract}

\section{INTRODUCTION}

In Indonesia, a country that is famous for its diversity, this plurality is marked by the existence of ethnic groups who have different ways of life. Cultural differences in Indonesia are caused by differences in history and cultural development of each ethnic group. To meet the needs of his life as a plural society what is needed is to merge in people's lives. This method can be done by establishing good interaction and communication with fellow individuals, groups and communities. ethnic migrants and native Kerinci people, existed for a long time and migrant traders have been banyang who settled in Kerinci specifically. 1) forms of social interaction between migrant ethnic groups and Kerinci native people: a) Relationships between migrant traders and Kerinci ethnic groups, b) the formation of merchant groups. 2) factors that encourage socio-economic relations between pendatag and Kerinci aboriginal people: a) there is a pattern of reciprocity between groups of traders, b) negotiating among traders, c) because Minang traders provide economic assets in Kerinci Regency. 3) the form of control of migrant communities over the Kerinci ethnicity: a) many who hold the grocery store Minang Traders, b) have high integrity, c) have ethics in trade.

Keywords-Social Interaction, Ethnicity, Mastery, Market

This interaction cannot be separated from human life and interests. Without interacting we will be difficult and will never understand at all with other people's circumstances. Key social interactions for understanding human social life. Humans are Zone politicon that are interdependent and establish social relationships between people in life, in addition to guidance for living in groups [11].

In interaction relationships that are intertwined can influence, change, or improve the behavior of other individuals or vice versa so that good cooperation can be established 
between the actors of social interaction. Social interactions can be positive or negative. As for the positive nature leads to a good cooperation, for example in terms of trading in the market group. The market itself is one of the most important institutions in an economy. Even from most economic phenomena related to the market. The market is also one of the main drivers of the dynamics of economic life. The functioning of the market as an economic institution is inseparable from the place of trade and activities carried out by buyers and traders [3].

The market as a means of gathering transactions between sellers and buyers of goods and services where these transactions generally occupy a strategic location and close to the settlement. Seen from Sungai Penuh market, there are various kinds of modern shopping places owned by some people who are not native to Kerinci ethnicity, but migrants who find the location. Not only modern markets, traditional markets can also hold a lot of these markets, namely migrants who can keep the market. Usually the person who holds or controls the settlement site is the native community or the original Trader in a place of his own area. Market activity is influenced by the interactions that exist with many people both between traders and buyers. In the market there are a variety of individuals who come from different ethnic groups and regions [4].

According [12] states that the social relationship between the perceptions of each party to the other party which is very influential at all on the ongoing social interaction. Based on these perceptions they give meaning to each other's presence or presence and will determine how to interact with one another. Such social relations generally apply and regulate reciprocal relationships between individuals or groups or ethnic groups in society.

Judging from the results of the [2] research entitled Social Interaction between Java and Bali in the village of Bawang Tirto Mulyo and Kehuripan Village in Bawang Regency. With the results obtained that the interaction between Java and Bali. That to unite the togetherness between migrants and local natives, the people of Java and Bali have cooperated to carry out activities in the form of taking care of their gardens. Assimilation, namely the tradition of visiting each other when there are friends who are having difficulties or happy news.

The research above shows that integration occurs in a pluralistic society in realizing social harmony. So as to create an orderly, peaceful and prosperous life. This is in accordance with the purpose of the birth of the Republic of Indonesia is to prioritize the interests of all its people. In addition, the objectives of the State of Indonesia are definitively set out in the fourth paragraph of the Preamble to the 1945 Constitution which includes:

"... Protect all the Indonesian people and all of Indonesia's blood spilled to advance public welfare, educate the nation's life, and participate in carrying out world order based on independence, eternal peace and social justice..."

That the government and the local authorities can contribute or protect their own citizens. In the smallest thing or big thing in the life of its people.

The results of research conducted by [1] show that Chinese citizens contribute more to the economy of the local community. The values of Confucianism that influence the success of the ethnic Chinese economy.

From the form of ruler to certain groups by using intellectual and moral consensus. This means that hegemony groups agree on the ideological values of the authorities. In other words if there is one who holds a leadership in an area not a local native, then the ideology implanted will become extinct. So for pemengang local authorities to be able to filter out good ideas for their citizens.

As happened in several markets found in the Sungai Penuh Market in Kerinci Regency. The people of Sungai Penuh City are heterogeneous and consist of various ethnic backgrounds, such as, Chinese, Minangkabau, Javanese, Indian and Malay. According to data from the Central Statistics Agency (Badan Pusat Statistik-BPS) Kerinci population in numbers 
based on the Census Against Religion and Ethnic Groups in 2016 as follows:

Table 1. Number and Percentage of Population According to Religion in 2016

\begin{tabular}{lcc}
\hline \multicolumn{1}{c}{ Agama } & $\begin{array}{c}\text { Jumlah Pemeluk } \\
\text { (Jiwa) }\end{array}$ & Presentase \\
\hline Islam & 54.990 & 87.18 \\
\hline Kristen & 17.489 & 6.96 \\
\hline Khatolik & 7,888 & 2,91 \\
\hline Khong hu cu & 4,499 & 0,05 \\
\hline Jumlah & 87,132 & 100 \\
\hline \multicolumn{2}{l}{ Source: Online Statistics, Kerinci in Numbers (2016: 78$)$} &
\end{tabular}

Based on the Central Bureau of Statistics census data above, the majority of Kerinci Regency residents are more followers of Islam with a percentage of $87.18 \%$, and adherents of other religions such as Christianity, Catholicism, Khong $\mathrm{Hu} \mathrm{Cu}$, comparative fewer than adherents of Islam.

Table 2. Population Based on Livelihoods in Sungai Penuh in Kerinci Regency 2016

\begin{tabular}{llc}
\hline No & \multicolumn{1}{c}{ Jenis Pekerjaan } & Jumlah \\
\hline 1 & PNS & 5,459 \\
\hline 2 & TNI/ABRI & 337 \\
\hline 3 & POLISI & 1,550 \\
\hline 4 & SATPOL PP & 450 \\
\hline 5 & Honorer & 3,450 \\
\hline 6 & Jasa & 1,150 \\
\hline 7 & Wiraswasta & 136 \\
\hline 8 & Swasta & 120 \\
\hline 9 & Anggota DPRD & 30 \\
\hline 10 & TenagaKesehatan & 1,105 \\
\hline 11 & Petani & 2,585 \\
\hline 12 & BuruhTani & 1,474 \\
\hline 13 & KaryawanKebun Teh & 279 \\
\hline 14 & PerangkatKota & 1,585 \\
\hline 15 & BelumBekerja & 1,350 \\
\hline & \multicolumn{2}{c}{ Jumlah } \\
\hline & $\quad$ Source: Data on Population and Civil Registry Office of Sungai Penuh City
\end{tabular}

Meanwhile, when viewed from the perspective of community livelihoods. In particular, Sungai Sungai City is full, half of the population of Sungai Penuh City are majority, as the State Civil Apparatus (ASN) Teachers and in the Government Service. However, Kerinci Communities in plantation areas such as in Kayu Aro, Sulak, Semurup, Sekungkung, Koto Keras prioritize farming and farming. Because the geographical location is very supportive and good land. Not only farming or farming, their crops are sold in traditional markets, and this also holds not only detailed people. However, those who dominated holding the market were more dominant migrant communities (initial observations on clothing traders in Sungai Penuh market).

Judging from the results of research conducted by [10] regarding "Communication between Bugis Ethnic Cultures and Mandar Ethnics in Trade interactions in the Parepare City senggol market" shows that the form of communication to sellers in Bugis Ethnic and Mandar Ethnics uses two ways, namely by 
using non verbal and verbal. The use of verbal is to use Indonesian and Buginese, because the Mandar Ethnic people are passive in the Bugis language, but the Mandar Ethnics prefer to use Indonesian Language will avoid from misunderstanding.

[9] Minang ethnics have special characteristics and Merantau traditions. The impetus of the first overseas tradition is to become better, secondly the existence of networks, thirdly trust. Of these three obstacles is social capital in the Minangkabau ethnic group. Kerinci community consists of Minang ethnic originating from 1940 is quite long, and overall 133,930 inhabitants because Sungai Penuh City has a population of $80 \%$ are Minangkabau ethnic origin of birth in West Sumatra. The Minangkabau Ethnicity and other Ethnics such as Chinese Ethnic, Indian Ethnic, Batak Ethnic and Javanese Ethnic are not included in the intense communication process and pattern.

Seen from the description above, multi ethnic diversity in the Sungai Penuh market in Kerinci, Jambi Province cannot be separated from the existence of good communication (interaction). Based on the data obtained, the researchers are interested in conducting research on the case, with the research title "Social Ethnic Interaction in Mastery in Sungai Penuh City Market in Kerinci Regency in Prepective Sociology".

\section{METHOD}

In researching Social Interaction between ethnic groups in the market control of Sungai Penuh in the City of Kerinci in Prepective Sociology using qualitative research methods that describe and analyze data in the form of words or human actions more deeply that cannot be explained by quantitative figures. In this study explore the meaning of behavior that occurs in human action. The meaning expressed is like the actions of people regarding an event so as to obtain data about the background and how the process of social interaction between traders in controlling the Market in Sungai Penuh City Market.

Here are some characteristics in qualitative research [6]: 1) natural, 2) are dynamic and developing, 3) research focus, 4) are descrip tive, 5) research objectives apply as research subjects, 6) research data is descriptive, 7) focusing on the subject's processes and interactions, 8) limited subject, 9) subject selection is done purposively, 10) personal contact directly, 11) human instruments, 12) prioritizing direct data, 13) data collection by observation involved, 14) the relationship between researchers and informants is intimate, 15) holistic perspective, 16) oriented in unique cases, 17) empathic neutrality, 18) data validity, 19) data analysis is carried out inductively, 20) emik Truth, 21) conclusions are subjective, 22) be flexible, 23) the importance of the deepest meaning, 24) the process of collecting and analyzing data simultaneously.

Furthermore, why is qualitative research used because qualitative research is an in-depth study by looking at, observing, and experiencing the problem to be investigated, especially the issue of "Social interaction between ethnic groups in market control in the markets of Sungai Penuh in the City of Kerinci Regency in a sociological perspective". According to the author this is a complex phenomenon that must be seen as a whole through in depth interviews (indepth interview). Qualitative researchers see that between researchers and informants can not be separated. Therefore, the data in the field must be verified by qualitative means [7].

This research was conducted at Sungai Penuh Market Sungai Penuh District Kerinci Regency Jambi. This location was deliberately chosen because it fulfills the requirements of the purpose of this study. The location of this research is the market center of Sungai Penuh City of Kerinci Regency which is diverse in multi-ethnic and various regions, including: Padang people, Thionghoa people, Indians, Malay people, Batak people and others.

The reason for choosing the research location in the Sungai Penuh market is because, one of them was a researcher who lived in Sungai Penuh City and an argument was made by several students about why only Minang people trade a lot here and the majority of languages in Kerinci speak Minang. So it makes it easier to obtain data and accurate information 
and this research can be done continuously so that saturated data is obtained.

\section{RESULTS AND DISCUSSION}

Sungai Penuh city is a city formed by the divisiov of a parent district (Kab. Kerinci) and one of the 11 Kabupaten or cities was established in 2008. On the basis of law No. 25 of 2008 concerning the formation of Sungai Penuh City in Jambi Province.

Sungai Penuh market as a center for community spending in the middle of Sungai Penuh city. Sungai Penuh city is a heterogeneuos society with diverse ethnic groups. Forms of social interacttion between ethnic members take plece intensively and long. In the traditional stucture of the existing stucture in the Sungai Penuh market is considered quite important because of various diverse there are associations of traders in establishing togetherness such as social gathering, attending traditional festivals, religious events and community service. Sungai Penuh tradisional market is considered to be very functional to establish relations between ethnic groups, the interactions of one religion with another religion.

One of the patterns used in market interaction is, 1) Pattern of trade reciprocity, where there is a reciprocal relatinship in the form of assistance from both financial and energy (mind). 2) Consumer pattern, consumers are unique and special things where consumers are the king in choosing a leve, of satisfaction in the market. Consensus in modern culture of social practice, core cultural values, ideas avd aspirations avd identity are oriented towards consumption. See positeve interaction between languages and ethnic exchanges and it is carried out intensively. Although the Kerinci people claim to use malay in public places, but dealing or communicating with other ethnic groups following the language that has been agreed upon by a group using the Minang language, even ethnic chinese and India speak MinangKabau more fluently than their owv etnic languages. No wonder when in communication between various ethnic group many use the Minang language.
Markets in Sungai Penuh city of Kabupaten Kerinci are interacting between Malays, Minangkabau, Chienese, Javanese and India. Malay conversations with various other ethnic group take place using indentity dilution becauce they have been socializing for a long time in normal daily life. Findings obtained in the study, 1) the proces of social interaction between ethnic migrants and native Kerinci people, had been iv a long time in the 1950s; 2) migrant communities have become part of the detailed society without losing culture and tradition and can even build changes within the country.

In the market control that is usually carried out by migrant communities because the Kerinci community earners prioritize farming and farming. Because the geographical location is very supportive and good land. Not only faming, their crops in traditional markers. Communication is a person's behavior through social interaction and taking action on what is governed by the meaning of the behavior. According to [5] communication is an action between two or more parties who conduct relationships in the form of mutual interpretation of messages conveyed by each party. It is through this interpretation that a person will manifest the reaction behavior on the intention of the other party.

Burke put forwad a model of an analysis that is seen when commenication is called dramatic pentod, namely 1 ) act or submission by a actor, 2) scene, namely the situation or setting of an action, 3) agent or actors, 4) agency or tools, suggestions that are used by actors in carrying out actions. Agency here includes channels, massages, strategies, intitutions and other, 5) purpose, namely the purpose and objectives of the action.

Kenduri is a form of event or activity in the form of a celebration carried out by the Kerinci community by offering prayers to the creator. Kenduri is a tradition of Kerinci farmers if the rice is harvested and fertile by making a party or eating together by all people living in the Kerinci Regency area. The event was attended by all ethnic groups in Kerinci Regency to implement and encourage farmers to be more prosperous and prosperous. 
Negotiation is where someone is given a view of the way conflicts between social actors are resolved or continue. According to [8] negotiation is one solution to a problem such as land disputes, differences of opinion in which the parties agree to resolve their problems through a process of deliberation and cooling. One seen in the process of market interaction Minang people are usually smart in negotiating and that is an advantage in the process of finding consumers in trading. Such a relationship is what makes the Kerinci community incapable of playing a role in trading in the market.

\section{CONCLUSIONS}

In the process of social interaction in the Sungai Penuh market, Kerinci Regency is influenced by ethnic, religious, and residential factors. In traditional institutions are quite functional in building an interaction between communities whose heterogeneous people because of diverse ethnic and ethnic cultures. the reality of understanding in multiculturalism is well conceptualized because of the nature of mutual understanding and understanding in various ethnic differences, and can contribute in several activities such as community service, festive events (traditional events), social gathering, religious events, as well as hereditary renewal of life. Involved in the market management include ethnic Chinese, Minangkabau, Kerinci ethnic. The form of market dominance is the existence of competition in the economy and conceptual understanding of sociology in harmony among traders rejects the existence of differences, being able to live respect, respect, in ethnic differences. Able to work socially and help as a form of national unity with the growth of interactions that are characteristic natural to strengthen social integration between ethnicities and ethnic differences to prosper the regional economy.

While cultural adaptation and assimilation form the understanding of the sociology of the river market of Sungai PenuhKerinci, other forms of society can actualize positively, namely by doing voluntary work and mutual cooperation.
The River City government is full of village officeor sub-districts can be proactive in allocating development planning in market developments to advance and prosper the market community. Other researchers should be able to conduct research on social interactions between ethnicities in other perspectives.

\section{ACKNOWLEDGMENTS}

In this study the authors would like to thank especially for the guidance of Dr. Susi Evanita, M.Si, who always guides in this writing and the informant who openly provides the information provided and especially to the two parents who encouraged me to finish completing this paper. I hope this article can contribute to the wider community, especially to market traders.

\section{REFERENCES}

[1] Arbi Yasin. Hegemoni Ekonomi Etnik Tionghoa Dipesisir Kabupaten Bengkalis Riau. (2017). Jurnal Ilmu Sosial, 8(3). Retrieved from arbi.yasin@uin.suska.ac.id

[2] Ayu Reza Ningrum. Interaksi Sosial Antar Jawa Dengan Bali di Desa Bawang Tirto Mulyo dan Desa Kahuripan Dalam Kabupaten Tulang Bawan. Tesis PIPS. Universitas Lampung

[3] Damsar. (2002). Sosiologi Ekonomi. Jakarta: PT. Raja Grafindo.

[4] Damsar. (2005). Sosiologi Pasar. Padang: Laboratorium Sosiologi Fisip Unand.

[5] Elly, M., Usman. (2011). Pengantar Sosiologi. Jakarta: Kencana.

[6] Idrus, M. (2009). Metode Penelitian Ilmu Sosial. Yogyakarta: PT. Gelora Akasara.

[7] Iskandara. (2009). Metodologi Penelitian dan Sosial (Kuantitatif dan Kualitatif). Jakarta: Gaing Persada Pers (GP Pers).

[8] Istijanto. (2007). Seni Menaklukan Penjual dengan Negosiasi. Jakarta: PT. Gramedia Pustaka Utama.

[9] Latief. (2002). Etnis dan Adat Minangkabau. Bandung: IKAPI. 
[10] Putri, Iqbal. (2018). Komunikasi Antarbudaya Etnik Bugis dan Etnik Mandar Dalam Interaksi Perdagangan Di Pasar Senggol Kota Parepare.

Jurnal FIS, 7(2). Misqsul11012@yahoo. com.

[11] Soekanto, Sarjono. (2015). Sosiologi Suatu Pengantar. Jakarta: PT. Raja Grafindo Persada.

[12] Soemardjan, Selo dan Soelaeman, Sumardi. (1998). Setangai Bunga Sosiologi. Jakarta: Rajawali. 